\title{
The Status of Criminological Theories in Turkey: A Brief Account
}

\author{
Özden Özbay*
}

\author{
Cumhuriyet University, Faculty of Communication, 58140 Sivas, Turkey
}

\begin{abstract}
The aim of this study is to evaluate the status of criminological theories in Turkey and to present some recommendations to follow in the future. Unfortunately, some sub-disciplines in social sciences in Turkey have been relatively less developed. This is especially valid for criminology or sociological studies of crime. More relavant to this paper, there have been a limited number of tests of western-originated criminological theories in Turkey. It is suggested that Turkish scholars test all the existing criminological theories in the context of Turkey and, more importantly, tend to develop criminological theories that reflect Turkish realities.
\end{abstract}

Keywords: Crime, Delinquency, Theory, Theory Development, Turkey.

\section{INTRODUCTION}

In Turkey, although especially political or ethnic types of violence have been very common since the 1970s in Turkey, social scholars have not shown much interest in the topic of crime or criminology in general (for example, see Akşit 1997; Dönmezer 1983; Özbay 2005). First criminology course was taught in 1953, first criminology book/journal published in 1973, and criminological theories received attention by the scholars were American (see, Hebenton and Jou 2005; Willis, Evans, and LaGrange 1999). To the author's knowledge, the first journal article written especially on criminological theories was published in the year of 1992 (Kaner 1992). Unfortunately, the first criminological theory book was published in the year of 2010 (Dolu 2010). Criminological text books in Turkey limited only to several books (Akıncı 2010; Demirbaş 2005; Dolu 2010; Dönmezer 1994; İçli 1999; Yücel 2003) $)^{1}$.

Although the production of theoretical criminological knowledge has been dominated by the studies of the Western World, especially the United States, Turkey (also, including a huge number of other countries) has been at the opposite side of the production of criminological knowledge (also, see Hebenton \& Jou

*Address correspondence to this author at the Cumhuriyet University, Faculty of Communication, 58140 Sivas, Turkey; Tel: +90 545 576-1074;

E-mail: ozden_ozbay@yahoo.com

${ }^{1}$ In the western world, although there are many criminological instititutes, research centers, and especially academic departments, it generally is not possible to mention such things in the Turkey of 2016. One strong possibility for the lack of interest especially in ethnic/political violence as one domain of criminology in Turkey is the historical existence of the authoritarian state tradition related especially to the ethnic issues since the foundation of the Turkish Republic in 1923. That is, ethnic topics have been made "academic taboos" by the state as well as social scientists (for an overview on the status of the Turkish criminology, crime and criminal justice until the year of 1980 , see Dönmezer 1983).
2005; LaFree 2007; Karstedt 2001; Willis et al. 1999). However, this pattern has been changing, and scholars from some other western and non-western countries in the World have started to test especially strain, social learning, control and some other theories since the beginning of the $21^{\text {st }}$ century. According to the assumption of the Western-born criminological theories based on the positivistic notion of epistemology, causes of crime occur beyond location and time (Antonaccio and Botchkovar 2016).

The main aim of the field of criminology is to examine structure of illegal acts and criminal justice and to create abstract principles. In order to succeed this aim, criminological studies are bound to test whether hypotheses based on theories created at a certain time and place valid for other contexts. That is, criminologists have to search for how differences in societal contexts change theoretical arguments (Liu 2007). In this respect, the aim of this paper is whether those crime theories that have been created in the developed world can be applicable to the explanation of criminal behavior in the context of Turkey (for a similar argument, for example, see Akers 2010; Bennett 2004; LaFree 2007; Zhang, Messner, \& Liu $2008)^{2}$.

The chief opposing argument against for the above thesis in the criminological literature is this ${ }^{3}$ : The existing criminological theories have been developed in economic, political, cultural contexts of a specific

\footnotetext{
${ }^{2}$ For the criminological theories and concepts that were developed outside the Western world, see Karstedt (2001) and Willis et al. (1999).

${ }^{3}$ There are four types of comparative research (Kohn 1987, cited in Bennet 2004): (a) Country is used as subject, (b) country is used as unit of analysis, (c) two or more countries are used as part of greater international system, (d) country is used as context. The present study belonged to the forth category. In the world, there have been a limited number of comparative criminological studies. According one recent account (Liu 2007), comparative criminological topics were under $\% 10$ out of the whole topics at criminology conferences in 2003.
}

E-ISSN: $1929-4409 / 16$ 
society (e.g., the United States), and therefore, they can not be generalizable to different societies (Cain 2000; DeFleur 1968; Karstedt 2001; Willis et al. 1999). At this point, there is the third way or possibility: Both local and universal can co-exist and interact with each other (Karstedt 2001; Pakes 2010). The current study tries to do a review of the existing individual-level research on criminological theories in Turkey, sum up the main results, indicate some deficiencies, and make some suggestions for the future studies on the development of theoretical criminology in Turkey.

\section{CRIMINOLOGICAL THEORIES IN TURKEY}

The previous criminological works in Turkey limited only to a description of very few western criminological theories "suitable" to the Turkish social context (Dönmezer 1983; Saran 1968). The criminological theories mentioned are anomie/strain, culture-conflict, differential association, and labeling.

Likewise, an increase in descriptive studies on criminological theories has been recently observed (Dolu 2009a; Dolu 2009b; Gök 2011; Göksu and Karakaya 2009; Kaner 1992; Kızmaz 2005a; Kızmaz 2005b; Kızmaz 2006; Kızmaz 2007; Ünal 2008). These studies have focused on deterrence (Dolu 2009a; Gök 2011; Kızmaz 2005b; Kızmaz 2007), rational choice (Gök 2011), social control (Kaner 1992; Kızmaz 2005a; Ünal 2008), differential association (Kaner 1992; Kızmaz 2005a; Ünal 2008), social learning (Kızmaz 2005a) labeling (Göksu and Karakaya 2009; Kaner 1992; Kızmaz 2005a) routin activity/rational choice (Dolu 2009b; Kızmaz 2005a), social disorganization (Kaner 1992; Karakuş and Oguzhan 2010; Kızmaz 2005a), subculture (Kaner 1992; Kızmaz 2005a), classic strain theories (Kaner 1992; Kızmaz 2005a), neutralization techniques (Kaner 1992), conflict (Kaner 1992) and theory integration (Kızmaz 2006).

However, the number of the extant research on tests of theories of crime or delinquency has been very few (not to mention the absence of "local" crime theories or concepts): Merton's (1938) classic strain theory (Özbay 2003; Özbay 2008a; Özbay and Özcan 2006a); general strain theory (Özbay 2016; Özbay 2014; Özbay 2012; Özbay 2011); Hirschi's (1969) social control (bonding) theory (Çam 2010; Özbay 2004; Özbay and Özcan 2006b; Özbay and Özcan 2008; Ünal and Çukur 2011; Yüksek and Solakoglu 2016); and Gottfredson and Hirschi's (1990) selfcontrol theory (Özbay 2008b; Özbay and Köksoy 2009), neutralization techniques (Ferzan 2009), and an integration of classic strain and social control theories (Özbay 2008a). Although differential association/social learning theory has not been directly tested in Turkish context, however, the variables form this theory has been continously used as control variables in some studies (e.g., Özbay 2006b; Özbay 2015). The major findings of the individual studies regarding tests of these theories were explained in detail below.

\section{Strain/Anomie Theory}

\section{Classic Strain Theory}

The main thesis of Merton's (1938) classic strain theory is that when there exists a gap between aspiration and expectation of an individual at the bottom strata of a society, the individual will be more likely to commit crime. This theory was tested first by using 1.710 high school students in the central part of Ankara, the capital of Turkey in the year of 2001 in a cross-sectional study ("The Ankara High School Research"). According to the results of classic regresion analyses, classic strain theory played no or less role in the explanation of delinquent behavior (Özbay 2003).

Also, classic strain theory was tested in relation to the relationship between gender and delinquency by using the same data and theory. The findings indicated that the theory played a similar role for both male and female delinquency (Özbay and Özcan 2006a).

\section{General Strain Theory}

According to Agnew's general strain theory (Agnew 1992; 2006), deviant behavior is a result of negative emotions (anger, fear, disappointment etc.) originating from distasteful events or conditions (stresses). This central process was further affected by deviant (e.g., deviant friends) or non-deviant coping factors or strategies (e.g., religion).

By using the same data and the same independent variables (but different dependent variables), Özbay (2011; 2012; 2014; 2016), for the first time, tested a group of strain variables (and an index of the same strain variables) on various deviant behaviors at a university sample $(n=974)$ in the year of 2010 by using a cross-sectional design.

Starting with the first study (Özbay 2011), Özbay tested the impacts of twelve strain (e.g., perceived blocked opportunity, relative deprivation, best way to earn much money, wishes for living in a Western country, educational strain, lack of future employment 
opportunity, income-expense strain, monetary wishes and its realization, verbal harassment, course failures, family-conflict, teacher-related strain), one negative emotion (anger) and six coping variables (e.g., family control, belief) on some youth deviant acts (cheating, bribbery, and piracy) in a correlational analysis. In general, the findings gave limited support for general strain theory. Out of the overall 39 correlation cofficients between the strain variables and deviant acts, only 11 strain variables were significant. As expected, these strain variables were positively correlated with the dependent variables. Also, anger was positively correlated only with cheating. Only four coping variables were correlated with deviant acts, and their signs mostly were in the expected directions.

In the second study (Özbay 2012), Özbay tested the influences of strain index (e.g., the above twelve strain variables), the above negative emotion and coping variables on some "deviant" acts (smoking, alcohol use, violence, and cheating) on the basis of gender (male and female) by using a logistic regression analysis. The results showed that the cumulative strain, anger, and non-criminal coping factors had similar roles for both females and males, which challenged the gender differences thesis of the theory in question (also, see Özbay and Özcan 2006a for a simliar finding).

In the third study (Özbay 2014), Özbay tested general strain theory on substance use (alcohol and cigarette uses) by using the same strain, negative emotion, and coping variables through using a logistic regression analysis. The research demonstrated that most strain variables did not have any impacts on the substance use, which really questioned the one of the central thesis of the theory. Although anger did not have any effect on alcohol use, it had a positive effect on cigarette use. Among the six coping variables, only two were statistically significant: Belief and religion.

In the final study (Özbay 2016), Özbay tested general strain theory on violence by using the same strain, negative emotion, and coping variables via employing a logistic regression analysis. The study indicated that few strain variables had direct positive influences on the dependent variable. Anger was positively related to violence. Few interactions on the relationships between the strain and coping factors were noticed.

In sum, similar to the findings of classic strain theory of Merton above, the findings related to general strain theory were not seem to be promising for the explanation of deviant behavior of student populations in Turkey.

\section{Control Theory}

\section{Social Control (Bonding) Theory}

Hirschi (1969) asserted that when a person's bond to society is weak or broken, the person is more likely to engage in delinquent or criminal behavior. A first test of the theory was carried out by using the data from The Ankara High School Research mentioned above (Özbay and Özcan 2006b). According to the results of classic regression analysis, social bonding theory played an important role in the explanation of delinquency in Turkey. Stated in detail, those adolescents who had a greater level of attachment to family, attachment to teacher, family control, commitment to school, belief in conventional norms, they tended to commit less delinquent behavior, independent of the effects of age, gender, and social class.

By using the Ankara High School Research Data, Hirschi's theory was tested whether it accounted for the delinquent behavior of male and female equally (Özbay and Özcan 2008). Again, the research results pointed out that social control generally played a similar role in male and female delinquent acts. For instance, high family control explained a lesser involvement in school delinquency by both male and female adolescents.

One more time, social control theory was tested in connection with the relationship between age and delinquency by using data from The Ankara High School Research. The data were divided into three age groups: (a) "Early adolescence" (aged between 13-15), (b) "middle adolescence" (only 16 years old), and (c) "late adolescence" (aged between 17-20). The findings showed that social control theory accounted for more the delinquent behavior of middle and late adolescence than that of early adolescence. Moreover, concerning assault type of delinquency, family control was the strongest predictor of assault in the period of early adolescence. Yet, in the period of middle and late adolescence, gender (being female compared to being male) was the strongest variable in relation to assault. Also, as for school delinquency type of delinquency, commitment to school was the strongest predictor in all the three age groups. Finally, with regard to public disturbance type of delinquency, commitment to school was the strongest predictor in early adolescence, belief in conventional norms and values and respect for 
police in middle adolescence, and family control in late adolescence.

Also, Hirschi's social bonding theory was tested in relation to marijuana use by using data from The 2006 Youth in Europe Survey in a cross-sectional study (Çam 2010). The sample consisted of 2.740 high school students in the Neighborhood of Bagcilar, Istanbul. According to the logistic regression analysis, social bonding theory generally was received support. For example, students with greater attachment to family and school, a higher school commitment, and a greater belief in conventional society were less opt to involve in use of marijuana.

Likewise, Yuksek and Solakoglu (2016) tested the attachment dimension of social bonding theory (parental, deviant peers, and school) in relation to a group of delinquent acts (school absenteeism, propensity to engage in physical aggression against others, propensity to take illegal substances, and propensity to not to follow rules) by using The Youth in Europe Survey Data through employing Negative Binomial and OLS in a cross-sectional study ( $n=$ 2.445). This research indicated that the greater the attachment to school, the lesser the delinquency. Also, they found that attachment to parents and deviant peers mediated the link between school alienation and delinquency.

Finally, Ünal and Çukur (2011) tested such social bonding variables as attachment to school and commitment to school against such delinquent acts as property, violence, school delinquency, and substance use as well as victimization as the dependent variables in the high schools of the city of Izmir in the years of 2008 and 2009 by using Tobit regression analysis in a cross sectional study $(n=3.742)$. The findings showed that although attachment to school was not statistically significant, commitment to school had negative impacts on all the dependent variables.

\section{Self-Control Theory}

According to self-control theory (Gottfredson and Hirschi 1990), an indiviudal with a low self-control in the presence of opportunity is more likely to engage in criminal behavior. Self-control theory was tested in relation to violence by using sample of 974 undergraduate students at a public state university in a small city, Nigde, in 2004 in a cross-sectional study (Özbay and Köksoy 2009). The findings indicated that the lower the self control, the greater the violence. However, sub-dimensions of self control concept did not have consistent significant impacts on youth violence.

Moreover, self control theory was tested whether it had explained male and female crime similarly by using the same data (Özbay 2008a). As before, it was reported that self-control theory played similar role in male and female criminal behavior.

\section{Learning Theory}

According to differential association/social learning theory of Sutherland or Akers (Akers and Sellers 2008), criminal behavior is a consequence of imitation (e.g., modeling of other people's criminal acts), differential reinforcement (e.g., instrumental learning via punishments and rewards), definitions (e.g., criminal beliefs, attitudes), and differential associations (e.g., criminal friends).

Although there have been direct tests of learning theory, it, however, has been indirectly tested as "control variables" in some of the studies mentioned in this article (Özbay 2004; Özbay 2006; Özbay and Özcan 2006; Özbay 2009; Özbay 2011; Özbay 2012; Özbay 2014; Özbay 2013; Özbay 2015). Among the learning variables, differential association and criminal definitions were frequently used in the Turkish studies (that is, the two major concepts from differential association theory of Sutherland). The Turkish studies showed that having delinquent or deviant friends, as expected, had positive impacts on juvenile delinquency such as total delinquency, assault, school delinquency, public disturbance (Özbay 2004; Özbay 2006; Özbay and Özcan 2006) and youth deviant acts such as current deviance, violence, cheating, bribbery, piracy, alcohol use (Özbay 2013; Özbay 2011; Özbay 2012; Özbay 2014, Özbay 2015). "Definitions" (beliefs, attitudes) supporting delinquent acts were positively related to such delinquent acts as total delinquency, assault, school delinquency, and public disturbance (2006b).

\section{Neutralization}

Furthermore, according to Sykes and Matza (1957), neutralization techniques is the reason behinde delinquent act. The techniques are excuses and justifications for engagement in delinquency (Akers and Sellers 2004). The neutralization theory was used to explore the perceptions of the Turkish police captains graduated from the Turkish Police Academy in the year of 1998 in a cross-sectional study (Ferzan 2009). The following findings were obtained: First, the Turkish 
criminals utilized neutralization techniques. Second, the neutralization techniques were used for some crimes, but not others. Finally, neutralization varied according to types of crime: Those who used substance and committed terrorism were utilized all neutralization techniques; those engaged in property and violence utilized to a moderate degree; and those involved in sexual crimes utilized none or less.

\section{Theory-Integration}

There has been only one study that tested an integration of classic strain and social bonding theory by using data from The Ankara High School Research (Özbay 2008b). According to the result of the path analysis, the impact of strain variables on delinquency was mediated by social bonding variables. That is, this research indicated that the variables from social control (bonding) theory played a more significant role in the explanation of delinquent behavior than the variables from classic strain theory. More important, social bonding theory variables completely mediated the link between strain and delinquency. So, this implied that although strain was an important factor for the account of delinquency, however, some preventive mechanisms were active in "blocking" strain to result in delinquent behavior.

The above studies can be critized on several grounds: First and foremost, because there are very few applied studies on theoretical criminology in Turkey, the findings should not be interpreted in the strict sense of the word. Second, the research only tested a very limited number of theories of delinquency/crime in the extant literature. Third, since the existing research used only a cross-sectional research design, prior criminal act was not controlled for. The previous research indicated that prior criminal behavior is one of the important correlates of delinquency/crime. Forth, owing to the fact that the data came from several different cities, they were not representative of the whole country. Fifth, as pointed out by Antonaccio and Botchkovar (2016), the measurements of some variables in the present study were limited to categorical variables instead of interval variables (e.g., "level of measurement" problem). Sixth, most data came from student or youth data which did not represent adult section of the Turkish society or "criminal" population.

\section{CONCLUSION}

On the basis of the above findings, some tentative arguments would be valuable at this point. First, such western theories as strain, social control, self-control, social learning, and neutralization techniques were received some support from the data used in the aforementioned studies with exception of classic or modern versions of strain theory.

It was important to highlight that social bonding, social learning, and self-control theories appeared to be receiving great support from the Turkish context. The major reason behind this support seemed to reflect the traditional socio-cultural aspects of the Turkish society (importance of family and friends, impatient personality trait etc.).

However, although the impacts of strain variables were weak and rare in general (e.g., Özbay 2003), when they were significant, their impacts were cancelled out by social control variables (Özbay, $2008 \mathrm{~b})$. Although the research indicated absence of the impact of "instrumental social support" on various deviant behavior among the youth sample (Özbay 2011; Özbay 2012 Özbay 2014), one strong possibility for the blocking effects of social control came from the principle of the Turkish Constitution (the notion of "social state"). Unlike most state-defined principles, it is probably the most realized principle due to its cultural correspondence in Turkish society. That is, the behavior that socially and officially support for the weak sections of the population is relatively pervasive, hence, an important value. Stated more specifically, people care socially and financially each other in difficult times in Turkey (for an excellent description of "social support," see Colvin, Cullen, and Vander Ven 2002).

Given that the theories developed in western societies with a different social, cultural, economic, political backgrounds were valid in the context of Turkey, most findings here seemed to be challenging "culture-specific" explanations of criminological theories (for a similar accounts, see Hebenton \& Jou 2005; Liu 2007; Zhang, Messner, Liu 2008; for a contradictory argument see Antonaccio and Botchkovar 2016). Likewise, strain, social control, and self-control theories played a similar role for male and female illegal behavior in Turkey. Although it is too early to highlight imporatance of theory-integration in the context of Turkey, it has recently been suggested that "some kind of integrated theoretical perspective may be needed to address the issue of crime causality satisfactorily" (Antonaccio and Botchkovar 2016, p. 575).

The status of the Western criminological theories in the Turkish criminological studies has been 
summarized and critiqued in this study. The Turkish criminological works are repeation studies in essence. Of course, this type of deductive studies are necessary at the beginning of Turkish criminological theory development. More important, local concepts and theories should inductively be incorporated into the existing Western criminological theories (Willis et al. 1999; at this point, one important methodological way is to develop crime theories through case studies, see Arthur and Otwin 1995; Liu 2007). For example, "Siri," a concept in Indonesian culture, corresponds to an individual or his/her family's respectability, name, and honor. If an individual's siri is belittled in front of other people, it must be responded with a violent behavior. In the siri, violent act is a consequence of desire to sidestep societal abashment (Willis et al. 1999).

Likewise, Dilmaç (2016) argued that certain type of honor ("civic honor" or "şeref" in Turkish in contrast to "barbarous" honor like honor killings, crimes of customs, and vendetta) in Turkey works as a regulating mechanism in daily social interactions and prevent deviant acts. She argued that (2016, p. 310 $)^{4}$ :

"Şeref is necessary as personal principles, geared toward the social recognition of others, made possible through self-control of body and impulses. [...], this meant a principle of containment and restraint, forming a civic honor that attempted to be "civilized.' " Also,

"The without şeref leads an infra-social existence, since through his/her conduct he/she has breached the code of honor (...). This is why individuals fear loss of honor is so much. Additionally, ... it was better to die than to be perceived as without şeref. Individuals therefore cannot choose to ignore şeref, which would mean accepting exclusion and social death." ( $p$. 305)

In Turkey, Özbay (2008c) claimed that when some individuals use "torpil" (or getting personal advantages in "amoral" and "illegal" ways through close social network of "partner-friends-relatives"), some other individuals, as a result, feel relatively and socially deprived. To describe this type of deprivation

${ }^{4}$ Dilmaç, at the very end of her article, however argued that şeref also lead to "symbolic violence!" See Colaguori (2010) for Bourdieu's notion of "symbolic violence." (differerent from economic deprivation in the sense of being "social"), he created the concept "relative social capital deprivation." Özbay argued that if an individual has higher degree of relative social capital deprivation, the individual is more likely to engage in some types of crimes. He tested this concept with a single indicator and found that higher relative social capital deprivation led to an increase in alcohol use and violence among youths in a strong clientelistic type of society, Turkey (see Hicken, 2011 for notion of clientelism).

In a global world, it was argued that the main task for criminologists is to go back and forth systematically between local and universal (Karstedt 2001; Pakes 2010). Reintegrative shaming developed by Braithwaite is an illustrative of this agument: The concept shame was derived from Asian societies, turned out to be a universal concept, and became a part of theoretical criminology (Karstedt 2001). If the Turkish criminological theory development follows this path, it will highly possible to contribute to both local and universal knowledge.

Last but not least, the findings here have some implications, at least, for a short-term solution to the ethnic/political violence between some section of the Kurds and Turks in Turkey which has been the most important issue since the beginning of the 1980s. Following the arguments made by Colvin, Cullen, and Vander Ven (2002), coercive or strain-leading factors or barriers (cultural, economic, or political ones) for the Kurdish side should be reduced or eliminated, and attachment to the mainstream society should be increased with a "social support" coming from both the state and its citizens. Otherwise, violence breeds violence!

\section{REFERENCES}

Agnew, Robert. 1992. "Foundation for a General Strain Theory of Crime and Delinquency." Criminology, 30: 47-87. http://dx.doi.org/10.1111/j.1745-9125.1992.tb01093.x

Agnew, Robert. 2006. Pressured Into Crime: An Overview of General Strain Theory, Los Angeles, CA: Roxbury Publishing Company.

Akers, L. Ronald. 2010. "The Challenge of Cross-Cultural Testing of Theory in Criminology Keynote Address for the Korean Society of Criminology in America" Speech Given at San Francisco in November, 18.

Akers, L. Ronald and Christine S. Sellers. 2008. Criminological Theories: Introduction, Evaluation, and Application. New York: Oxford.

Akıncı, S. Füsun. 2010. Kriminoloji. İstanbul: Beta Yayınevi.

Akşit, Bahattin. 1997. "Sosyoloji." Pp. 7-18 in Cumhuriyet Doneminde Türkiye'de Bilim: Sosyal Bilimler edited by TUBA. Ankara: Türkiye Bilimler Akademisi (TÜBA) Yayınları. 
Antonaccio, Olena and Ekaterina V. Botchkovar. 2016. "What International Research has Told Us about Criminological Theory?" Pp. 562-578 in Handbook of Criminological Theory edited by A. R. Piquero. Malden, MA: Wiley Blackwell.

Arthur, A. John and Otwin Marenin. 1995. "Explaining Crime in Developing Countries: The Need for a Case Study Approach." Crime, Law \& Social Change, 23: 191-214. http://dx.doi.org/10.1007/BF01301636

Bennett, R. Richard. 2004. "Comparative Criminology and Criminal Justice Research: The State of Our Knowledge: Presidential Address." Justice Quarterly, 21: 1-21. http://dx.doi.org/10.1080/07418820400095721

Cain, Maureen. 2000. "Orientalism, Occidentalism and the Sociology of Crime." British Journal of Criminology, 40: 239-260. http://dx.doi.org/10.1093/bjc/40.2.239

Colaguori, Claudio. 2010. "Symbolic Violence and the Violation of Human Rights: Continuing the Sociological Critique of Domination." International Journal of Criminology and Sociological Theory, 3 (2): 388-400.

Colvin, Mark, Francis T. Cullen, and Thomas Vander Ven. 2002. "Coercion, Social Support, and Crime: An Emerging Theoretical Consenus." Criminology, 40 (1): 19-42. http://dx.doi.org/10.1111/j.1745-9125.2002.tb00948.x

Çam, Taner. 2010. Explaining Marijuana Use among Turkish Juveniles: A Test of Hirschi's Social Bonding Theory. Unpublished Dissertation, University of Texas, U.S.A.

DeFleur, B. Lois. 1969. "Alternative Strategies for the Development of Delinquency Theories Applicable to Other Cultures." Social Problems, 17: 30-39. http://dx.doi.org/10.2307/799890

Demirbaş, Timur. 2005. Kriminoloji. Ankara: Seçkin.

Dilmaç, A. Julie. 2016. "Honor in Everyday Life in Turkish Society: A Barrier against Deviance?" Deviant Behavior, 37 (3): 302314. http://dx.doi.org/10.1080/01639625.2015.1012415

Dolu, Osman. 2009a. "Rasyonel Bir Tercih Olarak Suç: Klasik Okul Düşüncelerinin Suçu Açıklama ve Önleme Kapasitesinin Değerlendirilmesi." Polis Bilimleri Dergisi, 11 (4): 89-120.

Dolu, Osman. 2009b. "Bir Fırsat Olarak Suç: Suçun Durumsal Belirleyicileri, Suç Fırsatları ve Rutin Faaliyetler Teorisi." Polis Bilimleri Dergisi, 11 (2): 1-30

Dolu, Osman. 2010. Suç Teorileri. Ankara: Seçkin.

Dönmezer, Sulhi. 1983. "Turkey", in, Elmer H. Johnson (ed.), International Handbook of Contemporary Developments in Criminology: Europe, Africa, the Middle East, and Asia, Westport, Connecticut: Greenwood, pp. 591-606.

Dönmezer, Sulhi. 1994. Kriminoloji. İstanbul: Beta.

Ferzan, Ibrahim. 2009. The Perceptions of Turkish Police Captains about The Use of Techniques of Neutralization (Neutralization Theory) by Turkish Offenders. Unpublished Dissertation, University of Nebraska at Omaha.

Gottfredson, R. Michael and Travis Hirschi. 1990. A General Theory of Crime. Stanford: Stanford University Press.

Gök, Özkan. 2011. "Suçun Önlenmesinde Fırsatın Rolü ve Suç Kontrolü Uygulamalarına Karşı Olası Tehditler." Polis Bilimleri Dergisi, 13 (1): 97-114.

Göksu, Turgut and Muhittin Karakaya. 2009. "Polisin Sapma Davranışlarının Etiketleme Kuramı Açısından Değerlendirilmesi." Polis Bilimleri Dergisi, 11 (4): 27-43.

Green, Penny. 2000. "Criminal Justice and Democracy in Turkey: The Paradox of Transition." In Criminal Policy in Transition, edited by P. Green and A. Rutherford. Oxford: Hart Publishing.

Hebenton, Bill and Susyan Jou. 2005. "In Search of Criminological Tradition: The Development of Criminology in Taiwan." Crime, Law and Social Change, 44: 215-250. http://dx.doi.org/10.1007/s10611-005-9002-4
Hicken, Allen. 2011. "Clientelism." Annual Review of Political Science, 14: 289-310.

http://dx.doi.org/10.1146/annurev.polisci.031908.220508

Hirschi, Travis. 1969. Causes of Delinquency. Berkeley: University of California Press.

İçli, G. Tülin. 1999. Kriminoloji. Ankara: Bizim Büro Basımevi.

Kaner, Sema. 1992. "Suçluluğu Açıklayan Yaklaşımlar." Ankara Üniversitesi Eğitim Bilimleri Fakültesi Dergisi, 25 (2): 473-496.

Karakuş, Önder and Oğuzhan Başıbüyük. 2010. "Sosyal Düzensizlik Teorisi ve İnsan Ticareti: Sistemik Kontrol Yaklaşımı." Polis Bilimleri Dergisi, 12 (2): 23-41.

Karstedt, Susanne. 2001. "Comparing Cultures, Comparing Crime: Challenges, Prospects and Problems for a Global Criminology." Crime, Law and Social Change, 36: 285-308. http://dx.doi.org/10.1023/A:1012223323445

Kızmaz, Zahir. 2005a. "Sosyolojik Suç Kuramlarının Suç Olgusunu Açıklama Potansiyelleri Üzerine Bir Değerlendirme." Cumhuriyet Üniversitesi Sosyal Bilimler Dergisi, 29 (2): 149-174.

Kızmaz, Zahir. 2005b. "Ceza veya Kriminal Yaptırımın Suç Oranları Üzerindeki Caydırıcı Etkisi." Afyon Kocatepe Üniversitesi, Sosyal Bilimler Dergisi, 7 (2): 221-245.

Kızmaz, Zahir. 2006. "Kriminolojide Yeni Yönelimler: Bütünleşik Suç Kuramları II." Fırat Üniversitesi Sosyal Bilimler Dergisi, 16 (1): 305-335.

Kızmaz, Zahir. 2007. "Cezaevinin ve Hapsetmenin Suçu Engellemedeki Etkisi." Dumlupınar Üniversitesi Sosyal Bilimler Dergisi, 17: 44-69.

Kohn, L. Melvin. 1987. "Cross-national Research as an Analytic Strategy." American Sociological Review, 52: 713-731. http://dx.doi.org/10.2307/2095831

LaFree. 2007. "Expanding Criminology's Domain: The American Society of Criminology 2006 Presidential Address." Criminology, 45: 1-31. http://dx.doi.org/10.1111/j.1745-9125.2007.00070.x

Liu, Jianhong. 2007. "Developing Comparative Criminology and the Case of China: An Introduction." International Journal of Offender Therapy and Comparative Criminology, 51: 3-8. http://dx.doi.org/10.1177/0306624X06295774

Merton, K. Robert. 1938. "Social Structure and Anomie." American Sociological Review, 3 (5): 672-682 http://dx.doi.org/10.2307/2084686

Özbay, Özden. 2016. "Violence among the Youth in Turkey: An Assessment of General Strain Theory." International Journal of Criminology and Sociology, 5: 55-67. http://dx.doi.org/10.6000/1929-4409.2016.05.05

Özbay, Özden. 2015. "Does Islam Deter from Crime in a Secular Islamic Country? The Case of Turkey." Contemporary Social Science: 1-19.

Özbay, Özden. 2014. "General Strain Theory and Substance Use." Polis Bilimleri Dergisi (Turkish Journal of Police Studies), 1 81-102.

Özbay, Özden. 2013. "Does Social Status Lead to Social Deviance in Turkey?" Tunceli Universitesi Sosyal Bilimler Dergisi, 2 (3): 1 19.

Özbay, Özden. 2012. "Gender, Cumulative Strain and Deviant Behavior in Turkey." Nevsehir Universitesi Sosyal Bilimler Enstitusu Dergisi, 2 (1): 43-63.

Özbay, Özden. 2011. "Does General Strain Theory Account for Youth Deviance in Turkey?" Nevsehir Universitesi Sosyal Bilimler Enstitusu Dergisi, 1 (1): 107-129.

Özbay, Özden. 2008a. "Strain, Social Bonding Theories and Delinquency." Cumhuriyet Üniversitesi Sosyal Bilimler Dergisi, 32: 1-16.

Özbay. Özden. 2008b. "Self Control, Gender, and Deviance among University Students in Turkey." Journal of Criminal Justice, 36: $72-80$. http://dx.doi.org/10.1016/j.jcrimjus.2007.12.009 
Özbay, Özden. 2008c. "Does Social Capital Deter Youth From Cheating, Alcohol Use, and Violence in Turkey?: Bringing 'Torpil' In." Journal of Criminal Justice, 36 (5): 403-415. http://dx.doi.org/10.1016/j.jcrimjus.2008.07.006

Özbay, Özden. 2006. "Class and Self-Reported Juvenile Delinquency: Evidence from Turkey." Journal of Criminal Justice, 34: 237-249. http://dx.doi.org/10.1016/j.jcrimjus.2006.03.007

Özbay, Özden and Yusuf Z. Özcan. 2006 "A Test of Hirschi's Social Bonding Theory on Juvenile Delinquency in the High Schools of Ankara, Turkey." International Journal of Offender Therapy and Comparative Criminology, 50: 711-26. http://dx.doi.org/10.1177/0306624X05283525

Özbay, Özden. 2003. "Merton's Strain Theory: Evidence from the High Schools in Ankara." Cumhuriyet Universitesi Sosyal Bilimler Dergisi, 27: 59-76.

Özbay, Özden. 2004. "Age, Delinquency, and Social Bonding Theory." Sosyoloji Arastırmaları Dergisi, 7: 53-75.

Özbay, Özden and Onur Köksoy. 2009. "Is Low Self Control Associated with Violence among Youth in Turkey?" International Journal of Offender Therapy and Comparative Criminology, 53: 145-167. http://dx.doi.org/10.1177/0306624X08314577

Özbay, Özden and Yusuf Z. Özcan. 2008. "A Test of Hirschi's Social Bonding Theory: A Comparison of Male and Female Delinquency." International Journal of Offender Therapy and Comparative Criminology, 52: 134-157. http://dx.doi.org/10.1177/0306624X07309182

Özbay, Özden and Yusuf Z. Özcan. 2006a. "Classic Strain Theory and Gender: The Case of Turkey." International Journal of Offender Therapy and Comparative Criminology, 50: 21-38. http://dx.doi.org/10.1177/0306624X05277665

Özbay, Özden and Yusuf Z. Özcan. 2006b. "A Test of Hirschi's Social Bonding Theory on Juvenile Delinquency in the High Schools of Ankara, Turkey." International Journal of Offender Therapy and Comparative Criminology, 50: 711-26. http://dx.doi.org/10.1177/0306624X05283525
Pakes, Francis. 2010. "The Comparative Method in Globalised Criminology." The Australian and New Zealand Journal of Criminology, 43: 17-30. http://dx.doi.org/10.1375/acri.43.1.17

Saran, Nephan. 1968. İstanbul Şehrinde Polisle İlgisi Olan Onsekiz Yaşından Küçük Çocukların Sosyo-kültürel Özellikleri Hakkında Bir Araştırma. Istanbul: Tas Matbaası.

Sutherland, H. Edwin and Donald R. Cressey. 1978. Criminology (10 ${ }^{\text {th }}$ Ed.). Philadelphia, U.S.: J.B. Lippincott Company.

Sykes, M. Graham and David Matza. 1957. "Techniques of Neutralization: A Theory of Delinquency." American Sociological Review, 22: 664-670. http://dx.doi.org/10.2307/2089195

Ünal, Halime. 2008. "Neden Çocuklar ve Gençler Suç İşler? Ayırıcı Birleşimler ve Sosyal Kontrol Teorileri." Toplumbilim, (23): 51-62.

Ünal, Halime and Cem Ş. Çukur. 2011. "The Effects of School Bonds, Discipline Techniques in School and Victimization on Delinquency of High School Students." Kuram ve Uygulamada Eğitim Bilimleri (Educational Sciences: Theory \& Practice), 11(2): 560-570.

Willis, L. Cecil, Thomas D. Evans, and Randy L. LaGrange. (1999). “ 'Down Home' Criminology: The Place of Indigenous Theories of Crime." Journal of Criminal Justice, (27): 227-238. http://dx.doi.org/10.1016/S0047-2352(98)00061-0

Yücel, M. Tören. 2003. Kriminoloji. Ankara: Başkent Matbaası.

Yüksek, A. Durmuş and Özgür Solakoğlu. 2016. "The Relative Influence of Parental Attachment, Peer Attachment, School Attachment, and School Alienation on Delinquency among High School Students in Turkey." Deviant Behavior, 37 (7): 723-747. http://dx.doi.org/10.1080/01639625.2015.1062683

Zhang, Lening, Steven F. Messner, \& Jianhong Liu. 2008. "A Critical Review of Recent Literature on Crime and Criminal Justice in China: Research Findings, Challenges, and Prospects (Introduction). Crime, Law and Social Change, 50: 125-130. http://dx.doi.org/10.1007/s10611-008-9134-4

Received on 13-06-2016

\section{DOI: http://dx.doi.org/10.6000/1929-4409.2016.05.14}

(C) 2016 Özden Özbay; Licensee Lifescience Global.

This is an open access article licensed under the terms of the Creative Commons Attribution Non-Commercial License (http://creativecommons.org/licenses/by-nc/3.0/) which permits unrestricted, non-commercial use, distribution and reproduction in any medium, provided the work is properly cited. 